\title{
Feasibility of Improving Cone Beam CT Number Consistency with a Scatter-Correction Algorithm
}

J. Li

Thomas Jefferson University and Hospitals

W. Yao

Eastern Health, St. John's, Canada

Y. Xiao

Thomas Jefferson University and Hospitals

Y. Yu

Thomas Jefferson University and Hospitals

Follow this and additional works at: https://jdc.jefferson.edu/bodinejournal

Part of the Oncology Commons

Let us know how access to this document benefits you

\section{Recommended Citation}

Li, J.; Yao, W.; Xiao, Y.; and Yu, Y. (2010) "Feasibility of Improving Cone Beam CT Number Consistency with a Scatter-Correction Algorithm," Bodine Journal: Vol. 3 : Iss. 1 , Article 14.

DOI: https://doi.org/10.29046/TBJ.003.1.013

Available at: https://jdc.jefferson.edu/bodinejournal/vol3/iss1/14

This Article is brought to you for free and open access by the Jefferson Digital Commons. The Jefferson Digital Commons is a service of Thomas Jefferson University's Center for Teaching and Learning (CTL). The Commons is a showcase for Jefferson books and journals, peer-reviewed scholarly publications, unique historical collections from the University archives, and teaching tools. The Jefferson Digital Commons allows researchers and interested readers anywhere in the world to learn about and keep up to date with Jefferson scholarship. This article has been accepted for inclusion in Bodine Journal by an authorized administrator of the Jefferson Digital Commons. For more information, please contact: JeffersonDigitalCommons@jefferson.edu. 


\title{
Feasibility of Improving Cone Beam CT Number Consistency with a Scatter-Correction Algorithm
}

\author{
Li, J., ${ }^{1}$ Yao, W., ${ }^{2}$ Xiao, Y., ${ }^{1}$ Yu, Y. ${ }^{1}$ \\ ${ }^{1}$ Department of Radiation Oncology, Thomas Jefferson University and Hospitals, Philadelphia, PA \\ Eastern Health, St. John's, NLAIB 3V6 Canada
}

\section{Purpose}

To explore the feasibility of improving Elekta cone beam CT (CBCT) number consistency using a scatter-correction algorithm, with the aim of using CBCT images for treatment planning with heterogeneity correction.

\section{Method and Materials}

A Gammex tissue phantom was scanned with and without a 1-cm bolus on an Elekta XVI cone beam CT. A scatter-correction algorithm was applied to process the projection images, where the first order scatter fluence was expressed as a function of the primary photon fluence, and iterations were performed to estimate primary and scatter fluences from the projections, assuming higher-order scatter fluence was constant or proportional to the first order scatter fluence. Volumetric images were reconstructed with the projection images. CBCT numbers of the insert rods of the Gammex phantom were compared between images with and without bolus, and with and without scatter-correction processing. Single field treatment plans with heterogeneity correction were generated using CBCT-toelectron-density conversions obtained in the images without the bolus, which were compared with the plans generated using CT images.

\section{Results}

CBCT numbers of the same insert rods were different in the images with and without bolus. Without the scatter-correction processing, the maximum, mean, and minimum differences of the CBCT numbers between bolus and no-bolus images were 485,128 , and 40 , respectively. After the processing, the corresponding differences were reduced to 349,80 , and 4 , respectively. The CBCT plans which were based on the processed images, show better dose agreement with the CT plans: for example, in the bolus plans, without the processing, the difference of the dose at isocenter was $7.1 \%$; after the processing, the difference was reduced to $0.8 \%$.

\section{Conclusion}

CBCT number consistency was improved by use of the scatter-correction algorithm. It is expected that with further improvement, the algorithm can be used in clinical applications. 